\title{
Progressive Education in Indonesia: Insight from Soedjatmoko Thought
}

\author{
Asep Suraya Maulana ${ }^{1}$ dan Hendri Hermawan Adinugraha ${ }^{2}$ \\ ${ }^{1,2}$ IAIN Pekalongan
}

Info Artikel :

Diterima 12 September, 2020

Direvisi20 7 Oktober, 2020

Dipublikasikan 26 Oktober 2020

\author{
Keywords: \\ Critical analysis \\ Progressive education \\ Soedjatmoko thought
}

\begin{abstract}
ABSTRAK
Pendidikan merupakan investasi investasi jangka panjang untuk mempersiapkan sumber daya manusia yang berkualitas dalam menghadapi tantangan masa depan. Dijelaskan Soedjatmoko, ciri dan kemampuan seperti apa yang harus dimiliki manusia Indonesia di masa depan. Tentu saja, karena beberapa fitur dan kemampuan yang diperlukan sudah jelas. Pertama, kita harus mendapat informasi yang baik. Kedua, kemampuan berkreasi menghadapi tantangan baru, serta kemampuan mengantisipasi perkembangan dan berinovasi. Ketiga, orang Indonesia harus memiliki harga diri dan kepercayaan diri yang dilandasi keimanan yang kuat. Melihat penjelasannya, tampak jelas bahwa tujuan pendidikan sebenarnya adalah rasa penghargaan yang tinggi terhadap realitas kemanusiaan. Kemanusiaan menurut Soedjatmoko merupakan kelanjutan dari humanisme dan memiliki orientasi dasar menuju kebebasan dan kesejahteraan manusia. Soedjatmoko memiliki perhatian yang cukup besar terhadap masyarakat Indonesia yang dari dulu sampai sekarang sedang dalam proses pembangunan pendidikan. Untuk merealisasikan pemikirannya, Soedjatmoko mengedepankan prinsip etika; pembebasan, tanggung jawab, konsensus, empati dan toleransi, nonkekerasan, modernisasi, dan agama. Kepedulian dan ide Soedjatmoko memang menginspirasi, bukan hanya bagi mereka yang pernah berinteraksi dengannya. Bahwa gagasan dan analisis Soedjatmoko secara keseluruhan karyanya berpusat pada aspek kemanusiaan sebagai jantung peradaban.
\end{abstract}

\begin{abstract}
Education is the investment of long-term investment to prepare human resources quality to face the challenges of the future. As explained by Soedjatmoko what kind of traits and abilities Indonesian human beings should have in the future. Of course, because some of the necessary features and abilities are obvious. First, we must be well informed. Second, the ability to be creative about new challenges, along with an ability to anticipate developments and innovate. Third, Indonesians must have self-esteem and self-belief, based on strong faith. Looking at the explanation, it seems clear that the purpose of actual education is a high sense of appreciation for the reality of humanity. Humanitarianism according to Soedjatmoko is a continuation of humanism and has a basic orientation towards human freedom and welfare. Soedjatmoko has considerable attention to the Indonesian people who from the beginning until now are in the process of educational development. To realize his thoughts, Soedjatmoko emphasized ethical principles; liberation, responsibility, consensus, empathy and tolerance, nonviolence, modernization, and religion. Soedjatmoko's concerns and ideas are inspiring, not just for those who have interacted with him. That Soedjatmoko's ideas and analysis as a whole his work is focused on the human aspect as the heart of civilization.
\end{abstract}

\section{Koresponden:}

Asep Suraya Maulana

Email: lanaasep977@gmail.com

\section{Introduction}

The progress of a country is very dependent on the progress of its education because education has made something very important in human survival, even education has become a kind of formula that is used as a pre-requisite for a nation to be called an advanced (modern) nation (Muhammad In'am Esha, 
2009). Therefore, the progress of a nation will be measured by how far the level of education that has been achieved by these nations. Education is a long-term investment to prepare qualified human resources to face future challenges (Ahmad Muzaki, 2013). This is a big challenge that must be done by a teacher to be able to fight for, guide and educate and direct their students to become a person who is the character, capable and intelligent as a whole and able to realize high human resources. Thus, the successors of this nation will become independent Indonesian people and noble characters.

As explained by Soedjatmoko, about the characteristics and abilities of Indonesian people in the future. Of course, because some of the features and abilities needed are clear. First, we must know well informed. We must realize that the learning process is never finished, that we must be able to enter the era of "lifelong learning" in this world that experiences rapid changes rapidly. Second, the ability to be creative about new challenges, together with an ability to anticipate development and innovation. Third, Indonesian people must have self-esteem and trust in themselves, based on strong faith. This will lead to the ability to be independent, initiate and try on their own and be able to compete (Soedjatmoko, 1991). Therefore, an educator must be able to recognize and accept the individuality of each of his students and continue to provide stimuli to think critically and creatively on their own.

Seeing this explanation, it is clear that the real purpose of education is a high sense of appreciation for the reality of humanity. Humanism arises from a doctrine that emphasizes human welfare (humanitarianism). Humanitarianism according to Soedjatmoko is a continuation of humanism and has a basic orientation towards human freedom and prosperity. Humanism is very concerned with religious values because its birth is strongly influenced by the spirit of religion. Then, in its development humanism wants to get closer to religion, but for humanitarianism it still prioritizes religion (Siswanto Masruri, 2014).

Soedjatmoko has a high level of attention towards the Indonesian people who from the past until now are in the process of developing education. Meanwhile, development according to Soedjatmoko is something that must be learned is not something that is done (Soedjatmoko, 1994). So in this case, education is very urgent for society and education must be able to instill in students also must be able to realize that they have rights, freedom and the possibility to take advantage of various opportunities and new opportunities without having to be influenced by external cultures. Because education is an activity of liberation, namely liberation from backwardness, fear, alienation and various other social conditions. Even further, that education must be able to influence the process of social change, by developing the values and culture desired to be developed in the form of various social institutions by the students (Dede Rosyada, 2004).

Education is also a vital element in every society, especially a democratic Indonesian society. Therefore, in a democratic society, it is hoped that the education system must be democratic. To make this happen, educators must help students in determining and choosing meaningful problems, finding relevant data sources, interpreting and assessing data accuracy and formulating conclusions. Educators must be able to recognize students, especially when they need special assistance in an activity so that they can continue their research. Educators are required to be patient, flexible, interdisciplinary, creative and intelligent (Siswanto, 2006).

Departing from this background, and with all its limitations in this paper, the author tries to examine Soedjatmoko's figure and thoughts based on the fact that he has succeeded in fighting for freedom and upholding human dignity, especially his thoughts in the field of education. Soedjatmoko's ideas or thoughts have a reputation at the international level and still have a point of relevance in the present context. Therefore, this paper will discuss the critical analysis of Soedjatmoko's progressive educational thinking, including Soedjatmoko's biography, Soedjatmoko's works, Human environment, values and Education according to Soedjatmoko, and critical analysis of Soedjatmoko's progressive educational thinking.

\section{Method}

Based on the shape, this study uses literature review research. This study uses a content analysis approach. This library research is considered suitable because it is natural and requires the integrity of the research data. In this study, an attempt can be made to describe the problem in depth through literature search activities on Soedjatmoko's thoughts through his phenomenal works and books.

\section{Results and Discussion}

Overview of Soedjatmoko's Biography 
With the name of Soedjatmoko Mangoendiningrat, Koko is the call of Soedjatmoko born in Sawahlunto on January 10, 1922. His mother and father made an affair on September 21, 1918, in Ponorogo. His father is Dr. Saleh Mangoendiningrat and his mother is Isnadikin. His mother and father were both born of Javanese noble families and therefore had privileges in terms of education. Formal education obtained by Saleh Mangoendiningrat is Indisch Arts, at STEVIA (School Tot Opleiding Inlansche Austen), on June 22, 1916. Since then, in 1916-1919 Saleh Mangoendiningrat has started his career as a doctor, assistant-Chirurgie in Batavia for three years. Then, Saleh Mangoendiningrat moved to West Sumatra, working as Chief of the Sawahlunto General Hospital for three years (1919-1922).

Furthermore, his father was transferred to the Hospital in Kediri for two years (1922-1924). His father also received a scholarship from the Dutch East Indies government to continue his studies in the Netherlands. On March 2, 1927, his father had successfully obtained a Europeesch Arts diploma at the University of Amsterdam. His father also won the Brevet Specialist Chirurgie (surgeon) and Brevet Gynecology (obstetrician). Then in 1929, his father won a doctorate in medical science at Gemeente Universiteit Amsterdam with a dissertation entitled: "Over Echinococcus" under the guidance of promoter Prof. Dr. Nodenboos. Then from 1945-1957, Saleh Mangoendiningrat served as Surakarta Residency Doctor concurrently as Lieutenant Colonel (titular); Professor at the "Cokroaminoto" College, Inspector, Head of the Central Java Provincial People's Health Service, Chair of the Indonesian Physicians Association, chancellor of Surakarta Cokroaminoto Islamic University until the end of his life (M. Nursam, 2002).

Regarding Soedjatmoko's education, formally from Kindergarten to Class II elementary school education in the Netherlands. Then, he entered ELS school until class VI in Manado. In Surabaya, Koko completed his ELS, then continued his studies at Hogere Burger School (HBS) in 1936. From HBS Koko continued his studies at the Gymnasium. After graduating from the Gymnasium, in 1940 Soedjatmoko then continued his education to the Geneeskundige Hoge School (HGS) or Medical Colleg (M. Nursam, 2002).

Soedjatmoko was a former Indonesian ambassador and intellectual who became the second chancellor at the United Nations (UN) University in Tokyo, Japan on September 1980. He was appointed by the UN Secretary-General in his consultations with the Director-General of UNESCO to replace the first rector, Dr. James M. Hester. Soedjatmoko was born as Soedjatmoko Mangoendiningrat. Around 1946, he began not to use the name Mangoendiningrat, because his father's name made him remember the aspects of feudalism in Indonesian culture. Seoedjatmoko indeed came from a noble family in Sawahlunto, West Sumatra. In 1943, when he took medical education in Jakarta, he was expelled from school because of his involvement in protests against the Japanese occupation and had a kinship with Sutan Sjahrir.

Then he moved to Surakarta and opened a medical practice with his father. In 1947, after Indonesian independence, Soedjatmoko and two other youths were sent to represent Indonesia in the United Nations (UN) in Lake Success, New York, United States. In 1952 he returned to Indonesia and joined the socialist press and the Indonesian Socialist Party. Soedjatmoko was elected as a member of Konstituante (19551959). As time went on, President Soekarno's government became increasingly authoritarian, Soedjatmoko began criticizing the government. To avoid censorship, Soedjatmoko worked as a guest lecturer at Cornell University in Ithaca, New York, for two years.

Soedjatmoko only returned to work in Indonesia after the failure of the September 30 Movement and the resignation of Sukarno to Soeharto as president of Indonesia. He was one of Indonesia's representatives at the United Nations (1966), then became the Indonesian Ambassador to the United States (1968), and at the same time, he received several honors doctorates. The man who was familiarly called by the call of Bung Koko was once an advisor to Foreign Minister Adam Malik. He also briefly became a member of several think tanks in the 1970s. After the Malari incident in January 1974, Soedjatmoko was arrested and interrogated for allegedly being the planner of the protest. He was finally released on the condition that he could not leave the country for two and a half years. In 1978 Soedjatmoko received the Ramon Magsaysay Award for International Relations, and in 1980 he was appointed Chancellor of United Nations University in Tokyo, Japan (Soedjatmoko, 2013).

\section{Soedjatmoko's Works and Thought}

There are several works by Soedjatmoko, which the authors can mention include:

a. An approach to Indonesian history: towards an open address before the Seminar on Indonesian History, Gadjah Mada University, Jogjakarta, Dec. 14, 1957.

b. Economic development as a cultural problem.

c. Asia in Mata Soedjatmoko, Jakarta: Kompas, 2010.

d. Human Dimension in Development. 
e. Soedjatmoko and Modernism, Notes on Soedjatmoko's Critical Thought.

f. Liberation Ethics (selection of articles about religion, culture, history, and science).

g. Culture and Socialist.

Soedjatmoko is a free scholar who is not bound by one of the disciplines. He is a scholar of "Border Crossers", because of his ability to cross the barriers of various disciplines, including historical disciplines. His ability to take distance allows him to be able to freely write about the object of study without being trapped or bound by the object of his study. Soedjatmoko's thoughts need to be reconstructed. Soedjatmoko, is also a true nationalist who loves his people, a Muslim whose views are broad, which in recent years often voiced his conviction that the healthy development of the Indonesian people would be achieved if the religions in the country managed to establish positive relations (Franz Magnis, 1993).

According to Crane Brinton (Gramedia, 1985: p.205-209) efforts to reconstruct this thought can be included in the systematic of historical disciplines of intellectual history categories that try to develop facts about who wrote what and when and in what form the results of his thoughts were published. On the requirements proposed by Brinton, Soedjatmoko's thoughts were very qualified to be tracked and examined. This effort then became very urgent because the theme of intellectual history in Indonesia, especially in universities, was still very lacking. The name Soedjatmoko can be said to be non-existent or call it missing in the reference lane as a contributor to our historical thinking in general. The variety of Soedjatmoko's thoughts as scholars "Border Crossers" of course Soedjatmoko's thinking is very diverse. Thought themes include science, education, culture, religion, history, and development. Nevertheless, something characteristic of Soedjatmoko is the nature of his love for the Indonesian homeland. The fruit of his globalized thinking has a starting point, which is based on the culture of the people who have that culture are the values that live in the community (Walan Yudhiani, 2014).

The themes of his thoughts are still very open to being studied and examined. The following will be briefly presented in the themes of his thoughts as follows:

\section{a. Field of Science and Education}

Soedjatmoko stressed the importance of science and education to be considered to be able to produce quality Indonesian humans. The so-called quality human beings are those who have consciously scientific disciplines, are critical and able to analyze and compile theories while maintaining clarity and honesty and scientific courage. Soedjatmoko's attention to educational institutions is not only limited to the tertiary level but covers primary and secondary education, which he considers to play a role in observing because the nation's scientific quality is partly important depending on the soul responses planted and cultivated at the elementary and secondary levels.

Some descriptions of his thoughts about science and education are contained in the following discourse:

1. Intellectual Role in Developing Countries (1970).

2. Some Thoughts About Higher Education (1975).

3. The Effect of Religious Education on Social Life (1976).

4. Ethics in the Formulation of the Social Sciences Research Strategy (1977).

5. Analysis of Wisdom and Development of Social Sciences in Indonesia (1976).

6. Cipta Power as an Absolute Element in Development; Conception and Institutionalization (1961).

7. Value System and Education about the Environment (1973).

8. Basic Needs Model: Implications in National Policy (1978).

\section{b. Field of Culture}

Soedjatmoko's thoughts on culture include the dynamism of culture which has the driving force and power of opponents of its changes whose dialectical form will show the vitality and personality of the nation and its culture. Politics and economics are also inseparable from cultural problems because they often manifest themselves in cultural form and influence in directing them. So that culture from generation to generation will continue to proceed as Clifford Gertz imagined that culture is a pattern of meanings that are intertwined thoroughly in symbols that are transmitted historically (Geertz, 1973: 89). Cultural practices will always undergo a process of reproduction, reconstruction, and even commodification of the risks of the passing of modernity. The final result of the transmission process depends on the actors in the cultural arena (Rosy Nukha, 2017).

The discourse of his thinking about culture is included in:

1. Why Confrontation (1954).

2. Pioneering the Future (1957). 


\author{
3. National Culture and Mental Mobilization (1960). \\ 4. Ahead of a Politics of Culture (1972). \\ 5. Indonesian in the Nation's Struggle (1978). \\ 6. Technology, Development, and Culture (1972). \\ 7. Dimensions of Structural Poverty (1980).

\section{c. Field of Religion}

Soedjatmoko's thinking about Religion is the same as his concern for science, education, and culture. Religion is seen to be closely related to various life problems. For Soedjatmoko, Religion is responsible for the effects of the development of science and technology that are not always positive and often bring havoc to humans. Soedjamoko is very confident that religious education will be able to foster the function of faith whose manifestations are in the form of charity. This is what in turn will encourage to participate in plunge and play a very important role in nation-building. Some of his thoughts about Religion are included in the discourse:

1. Outside Views and Inner Views: Encouragement to Go Forward (1965).

2. Sukma and Society: An Eastern Interpretation of Counter Culture (1969).

3. Religion and Development Process in Asia (1970).

4. Changes in Dialogue between Religion and Science (1974).

5. Faith and Development (1975).

6. Peace and dignity (1976).

\title{
d. Field of Development
}

In the framework of his thinking, Soedjatmoko wanted to get out of the conventional theories of growth on the one hand and structural theories that were revolutionary on the other. In this framework, "development can be seen as the willingness of the subject or a nation to achieve its dignity. Here that dignity does not by itself be guaranteed by economic growth. So to the theories that favor productive investment as the essence of economic growth, Soedjatmoko put forward the antithesis of the theory of economic development as a mobilization (Ema Khotimah, 2006).

Soedjatmoko explained that nation-building is not just an economy, but an integral part of all fields. The central point about this is humanity and its creative power in development efforts. The procession and the ultimate goal of development must be happiness and human freedom and personal rights, not just mere material sides. Soedjatmoko's thinking about Development besides being broken down in the 4 fields above, is also found in the following discourse (Soedjatmoko, 2010):

1. Economic Development as a Cultural Problem (1954).

2. Historical and Development Awareness (1976).

3. Futurology and Us: An Introduction to Description (1975).

4. Political Systems and Development in the Asian Research Agenda: A Devotional (1980).

5. Development and Human Rights (1979).

6. Development and Human Growth (1979).

\section{Human Environment, Values and Education according to Soedjatmoko}

According to Soedjatmoko, Indonesia has faced two kinds of problems regarding the human environment, namely; First, environmental problems caused by poverty and population density. Second, the problem of destruction and contamination of the environment caused by the development process. So in this case, Indonesia does not itself face human-environmental problems. However, even in poor countries and rich industrial countries have faced similar problems. Therefore, humans prepare themselves to always preserve nature, so that they can underlie and live the life of mankind in this world. In fact, in formulating a policy on the human environment, in essence, we are participating in planning the living conditions of future generations. Two aspects that we will binoculars, namely:

\section{a. Human settlements and human ratios with nature and the environment}

We cannot turn a blind eye to reality, most municipalities and big cities in Indonesia have been overwhelmed by the effects of urbanization. The rapid increase in the urban population is faster than population growth in society in general. This has resulted in threats to public health, increasing unemployment, housing shortages and lack of schools. The danger of the emergence of social tensions can threaten orderly city life and its citizens. 
Humans are confronted again with the main problem that has been faced since he realized he was a human handyman (homo fiber). That is what social goals to achieve with the tools they make. But the problem that he now faces is even more serious. As long as he lives in an industrial country society, the problem he faces is how humans can master the technology, and be able to control it to create a more human society. As far as humans live in poor countries, the problem is how can they avoid being ruled by the technology of rich countries, which are in accordance with their needs, and how they can develop technologies that are in accordance with their own needs that are in accordance with the resources available to them and can cross the mistakes made by industrial countries. In essence, both rich and poor countries face the same problem, namely how technology can be directed so that it can serve social goals, human aspirations, and society, by the needs of a world that will become increasingly narrow and dense (Soedjatmoko, 1995).

All of this shows the need for all the implications of changes in our society that will be caused by the extraordinary population density. Ethics are needed based on a new balance between human rights and social basic obligations. It should be realized how important it is to guarantee the quality and safety of human life, maintained and guaranteed by a variety of cultural cultures, as well as ecological stability will depend on maintaining the diversity of ecosystems. Humans are required to synergize with their suitability. Harmony with nature for humans, which is needed to face the future, is not a matter of knowledge and intellectual conception solely, it includes the issue of taste, namely the parent of our vision and thinking. So before humans come out to build the future through the results of technology and cultural works, the main thing is to first build humans themselves, build "feelings" and build "minds" (Sumasno Hadi, 2011).

For us Indonesians, efforts to ensure a decent, prosperous, just and secure life need to be built, not only in the new economic system to overcome poverty but more broadly. We need to build a new culture that re-establishes humanity as a protector and preserver of nature and all its wealth, and who can may hayuning bacon, that is to save the people and foster world prosperity, towards secrecy, safety, and secrecy (Soedjatmoko, 1995).

\section{b. Values and education}

Education in schools has the most important task, is to instill good values to be instilled in educators and students. Because value is a valuable thing, then in the outline there are three types, namely:

1. true-false value, this value is used in science (sain), all philosophy except certain school ethics.

2. good-bad value, this value is used in ethics (and the like).

3. beautiful value - not beautiful is a criterion used to determine the value of art, both motion art, sound art, painting, and sculpture.

In addition to these three types of values, we also recognize religious values such as halal, haram, sunnah and so on (Ahmad Tafsir, 2014). Therefore, the system or purpose of education must adhere to the values of Pancasila. Because in general, the purpose of education is nothing but wanting people to be better and better. The long-term process of printing quality human resources, of course, must require cooperation from various parties into a single entity, including the need for an education system that instills religious values, values human values, support and attention from the community, especially parents and the professional role of a teacher. Thus, the conditions of the education environment will be conducive to supporting students and improving better human resources. With the conception in the values of education like that, it will fulfill the life needs of humans to always exist (existential being, human-being, spiritual-being, to religiousbeing) (Abdul Wahab H. S., 2001).

According to Soedjatmoko, that a good education system, among others because of its ability to collect and develop knowledge systematically, becomes very important in educating a nation to formulate and overcome various problems (Soedjatmoko, 2010). Soedjatmoko invites us to develop an ethical framework regarding human safety and solidarity (an ethical framework for human survival and solidarity). So in the development of his thoughts, Soedjatmoko increasingly realized that social transformation turned out to have brought problems in the world of life (lifeworld) and the public sphere. Meanwhile, according to Muhammad Abduh, as quoted by Azyumardi Azra, said that education is a powerful instrument for making changes (Azyumardi Azra, 1999). These changes can be traversed through the process of giving knowledge (transfer of knowledge) to students, which is then called "education".

\section{Soedjatmoko's Thoughts on Human Development in the Quality of Educational Ethics in Indonesia}


In Indonesia, of course, there have been many thinkers and education experts who always try to study and find the right solution for the fate of education in Indonesia due to the influence of political policies, hegemony, and globalization. One of the leaders who have high enough attention to the fate of Indonesian nation-building is Soedjatmoko. He was a social thinker in the 20th century who owned Indonesia and also had a reputation at the international level. Soedjatmoko is a thinker in the fields of culture, philosophy, morality, politics, development and also education, even H.A.R. Tilaar called it a plenary social scholar (H.A.R. Tilar, 2009).

Soedjatmoko revealed the importance of the role of scholars in developing countries. The importance of scholars is primarily to place the country in the right direction of development, not in political analysis, which party will win or similar things (Soedjatmoko, 1984). For him, the role of scholars also determines the role of a link between the reality of his country and the development of the world.

In terms of education, Koko has ideas specifically about education in higher education. According to Koko, so far research in universities has been oriented to problems (problem-oriented), namely how to deal with problems that are occurring or will occur, whose scope is only short-term. So, the focus of academics in higher education is problem-oriented research, not research that was initiated by the university. This should not happen. This was also what he thought when he was Chancellor of the UN University. Universities that "collect" scientists from various countries are directed by Koko to become a research institution. But it is not research aimed at increasing the ease or pleasure of human suction, but the research that can prevent disasters that can occur on earth.

The role of university teaching was attributed by Soedjatmoko to the learning ability of a nation. Without this capacity improvement, the quality of university teaching will not improve. The function issue, according to Soedjatmoko, must be able to be more effective than what he has proven so far, linking the study of human and cultural sciences to moral problems both small and micro or large or macro, namely concerning social and national goals, including justice social, in national, regional and global contexts; also development issues involving efforts to find a more human form of society in the environment which also in the Third World is increasingly controlled by technology (Soedjatmoko, 1984).

Soedjatmoko is a prominent Indonesian scholar who has made an intellectual contribution to various aspects of humanity evolutionarily. Thanks to his reflection, study, experience, search and touch with the empirical world, his thoughts have undergone changes and developments. The peak of development and its greatest contribution is its thinking about humanity along with existential freedom orientation and human welfare that spread in various intellectual works. This is what led Soedjatmoko to the position of Indonesia's leading scholar with all the awards he received.

The central themes of Soedjatmoko's thinking include; politics, history, culture, education, freedom, development, economy, modernization, conflict, poverty, nonviolent struggle, peace, and religion. The evolution of Soedjatmoko's humanitarian thinking can be modeled into three periods: Nationalism (19401950s), Universal Humanism (1960-1970), and Humanitarianism (1980-1989's). The thinking in the last period was the main ideas and other thoughts which were the supporting ideas (Siswanto Masruri, 2002).

All of his thoughts, Soedjatmoko did not use much of the Qur'an, al-Sunnah, and other traditional Islamic sources. However, using the concept of substantialism and objectification of Islam, he is considered very concerned with universal humanitarian themes in Islam. He has shown that religion is the best solution in facing science and technology and modernity and that Islam is a religion of humanity (rahmatan li al-'Alamin). He never forgot his father's message that one thing to do was to practice Islam. the message is realized more substantively in the form of thought after he performed Umrah (1980).

Thus, the overall thinking of Soedjatmoko is an evolution of thought and antithesis (sometimes synthesis) patterns of humanitarian thought that developed during his lifetime: from nationalism to internationalism, from humanity to universal humanity, from oppression to freedom, from conflict to integration, from violence to non-violence, from national stability to social resilience, from centralized to decentralized, from rationalization to modernization, from sacralization to de-sacralization of the constitution, from products to development processes, from authoritarian to democratic, from political manifestations to cultural manifestations, from harmony to work interfaith, and from formalism to religious substantialism. To realize all that, Soedjatmoko indeed needs international cooperation and joint consensus on universal values towards human freedom and prosperity which are reflected in humanitarianism. The aim is development and peace-oriented to existential freedom and human welfare. To realize his thoughts, Soedjatmoko emphasized ethical principles; liberation, responsibility, consensus, empathy and tolerance, anti-violence, modernization, and religion (Siswanto Masruri, 2002).

Soedjatmoko's progressive concern and ideas certainly arouse inspiration, not only for those who have interacted directly with him. The boundary and never subsiding concern made his essay, when viewed thoroughly, appear to be a kind of veiled collection of love letters for a generation, a nation, a world, a 
realm of life, they would read it carefully, especially, a which was created in the last decade of Soedjatmoko's life, will be increasingly able to become citizens of the world who have roots in the country, with the spirit of humanitarianism and moral imagination that continues to expand to bring life and the world that supports it (Soedjatmoko, 2010).

Soedjatmoko's ideas and analysis as a whole are focused on the human aspect as the heart of civilization. Soedjatmoko, linking every dialectic problem starting from education, culture, history, religion to the development node in the form of changes in human values, lifted from poverty, structural poverty, and social justice towards free and autonomous humans. Soedjatmoko views freedom as a dynamic movement of man over the rapid change of the progress of science and technology.

Regarding it all, human development in the quality of education must be noble. Therefore, this goal can only be achieved through moral education, both directly and indirectly, because moral education is Ruh Al-Tarbiyah (Al-Abrasyi, 1969: 22). The purpose of moral education is not just to think about the world but to think together about the world and the hereafter, without looking at one side or one side (Imam Anas Hadi, 2018). As the prophet Muhammad Saw said, which means; "Whoever wants (happiness) lives in the world, then let them master knowledge, and whoever wants happiness (Happiness) lives in the hereafter, then let them master the knowledge, and whoever wants both, then master the knowledge." (Hadith) (Abdul Mujib, 2006).

\section{Conclusion}

Soedjatmoko revealed the importance of the role of scholars in developing countries. The importance of scholars is primarily to place the country in the right direction of development, not in political analysis, which party will win or similar things. For him, the role of scholars also determines the role of a link between the reality of his country and the development of the world. In terms of education, Koko has ideas specifically about education in higher education. According to Koko, so far research in universities has been oriented to problems (problem-oriented), namely how to deal with problems that are occurring or will occur, whose scope is only short-term. According to Soedjatmoko, that a good education system, partly because of its ability to collect and develop knowledge systematically, becomes very important in educating a nation to formulate and overcome various problems. Soedjatmoko invites us to develop an ethical framework regarding human safety and solidarity (an ethical framework for human survival and solidarity). So in the development of his thoughts, Soedjatmoko increasingly realized that social transformation turned out to have brought problems in the world of life (life-world) and the public sphere. Therefore, the progress of a nation will be measured by how far the level of education that has been achieved from the nation. Education is a long-term investment to prepare qualified human resources to face future challenges. Soedjatmoko has a high level of attention towards the Indonesian people who from the past until now are in the process of developing education. Meanwhile, development according to Soedjatmoko is something that must be learned is not something that is done. To realize his thoughts, Soedjatmoko emphasized ethical principles; liberation, responsibility, consensus, empathy and tolerance, anti-violence, modernization, and religion. Soedjatmoko's progressive concern and ideas certainly arouse inspiration, not only for those who have interacted directly with him. Soedjatmoko's ideas and analysis as a whole are focused on the human aspect as the heart of civilization.

\section{References}

Ahmad Muzaki. (2013). Gus Dur; Pembaharu Pendidikan Humanis Islam Indonesia Abad 21. Yogyakarta: Idea Press.

Abdul Wahab H.S. dan Umiarso. (2001). Kepemimpinan Pendidikan dan Kecerdasan Spiritual. Yogyakarta: Ar-Ruzz Media.

Ahmad Tafsir. (2014). Filsafat Pendidikan Islam, Integrasi Rohani, Jasmani dan Kalbu Memanusiakan manusia. Cet VI. Bandung: Remaja Rosdakarya.

Azyumardi Azra. (1999) Esai-Esai Intelektual Muslim dan Pendidikan Islam. Jakarta: Logos.

Dede Rosyada. (2004) Paradigma Pendidikan Demokratis, Sebuah Model Pelibatan masyarakat dalam Penyelenggaraan Pendidikan. Jakarta: Kencana.

Ema Khotimah, Pembangunan dalam Perspektif Ekofeminisme Analisis Kritis Paradigma Teori Pembangunan dan Urgensi Pembangunan Perspektif Demokratis Kulturis dalam Upaya Meningkatkan Indeks Pembangunan Manusia, MIMBAR, Jurnal Sosial dan Pembangunan, Volume XXII No. 3 Juli - September 2006. 
Franz Magnis-Suseno, Sj. (2009). Pengantar dalam Nusa Putra, Pemikiran Soedjatmoko tentang Kebebasan, Jakarta: PT. Gramedia Pustaka Utama,1993.

H.A.R. Tilaar, Kekuasaan dan Pendidikan; Manajemen Pendidikan Nasional dalam Pusaran Kekuasaan. Jakarta: Rineka Cipta.

Lihat Siswanto, Filsafat Progressivisme Dan Demokrasi Pendidikan; Menggagas Pembelajaran Demokratis, Tadrîs. Volume 1. Nomor 2. 2006.

Muhammad In'am Esha. (2009) Institusional Tranformasion; Reformasi dan Modernisasi Pendidikan Tinggi Islam. Malang: UIN Malang Press.

M. Nursam. (2002). Pergumulan Seorang Intelektual Biografi Soedjatmoko. Jakarta: Gramedia Pustaka Utama. Soedjatmoko. (2010) Bangsa Terdidik Menurut Soedjatmoko. Jakarta: PT. Kompas Media Nusantara.

Soedjatmoko. (1991). Soedjatmoko dan Keprihatinan Masa Depan, Yogyakarta: PT. Tiara Wacana Yogyakarta.

Soedjatmoko. (1995). Demensi Manusia dalam Pembangunan. Cet IV, Jakarta: Pustaka LP3ES.

Siswanto Masruri. (2014). Kemanusian Bersama; Pemikiran Humanitarianisme Soedjatmoko. Yogyakarta: SUKA-Press.

Siswanto Masruri. (2002) Menuju Humanitarianisme: Studi Evolusi Pola Pemikiran Kemanusian Soedjatmoko. Disertasi. Yogyakarta: IAIN Sunan Kalijaga.

Soedjatmoko. (1984). "Intelektual Negara Berkembang," dalam Etika Pembebasan. Jakarta: LP3ES.

Soedjatmoko. (1994) Pembangunan Sebagai Proses Belajar dalam Menjelajah Cakrawala; Kumpulan Karya Visioner Soedjatmoko, Jakarta: PT. Gramadia Pustaka Utama.

Sumasno Hadi. Pemikiran Sutan Takdir Alisyahbana Tentang Nilai, Manusia, Dan Kebudayaan. Jurnal Filsafat Vol. 21, Nomor 1, April 2011.

Walan Yudhiani. Kajian Studi Kultural Dan Pedagogik Dalam Pendidikan Indonesia, Jurnal Tarbiyah. Vol. 21, No. 2, Juli-Desember 2014. 